\title{
29. CONSOLIDATION CHARACTERISTICS AND PERMEABILITY OF BENGAL FAN SEDIMENTS DRILLED DURING LEG 116
}

\author{
Andreas Wetzel ${ }^{2,3}$
}

\begin{abstract}
The state of consolidation of outer Bengal Fan deposits is closely related to their depositional history. Early Pleistocene sediments are underconsolidated, i.e., fabric strength is lower than under equilibrium with the present overburden stress, at depths greater than $60-80 \mathrm{mbsf}$. This may be due to rapid accumulation $(>15-20 \mathrm{~cm} / \mathrm{k} . \mathrm{y}$.) and overlying low-permeability $\left(<10^{-7} \mathrm{~cm} / \mathrm{s}\right)$ deposits. The underlying Pliocene sediments are overconsolidated, i.e., fabric strength is higher than in equilibrium with the present overburden stress; at Sites 717 and 719 the sediments are slightly overconsolidated, whereas at Site 718 the overconsolidation is significant. Overconsolidation is explained by erosion that occurred during the early Pleistocene for which a stratigraphic gap was recorded in the drilled cores. The eroded section is estimated to be in the range of $10-40 \mathrm{~m}$ at Sites 717 and 719 , respectively, and $130-150 \mathrm{~m}$ at Site 718 . Below $250-300$ mbsf the most sediments are normally consolidated. The amount of erosion seems to be related to block rotation and uplift due to intraplate deformation.
\end{abstract}

\section{INTRODUCTION}

The outer Bengal Fan deposits investigated in this study were drilled during the Ocean Drilling Program Leg 116 at three sites about $800 \mathrm{~km}$ south of Sri Lanka in water 4,700$4,750 \mathrm{~m}$ deep (Fig. 1). The sediments were mainly deposited from turbidity currents interpreted as originating from the Ganges-Brahmaputra Delta (grey sandy, silty turbidites), the adjacent shelf (green silty to muddy turbidites), and Nikitin Seamounts (green fine-grained turbidites) (Stow et al., this volume). Clay-dominated pelagic intervals sometimes also occur at the top of turbidites.

At all three sites sediments of similar composition and lithology were found; they differ only in the thickness of the defined lithologic units (Fig. 2). Sedimentation is dominated by turbidites which on average reach the distal Bengal Fan at a frequency on the order of one every $>500$ years (Stow et al., this volume). The sedimentation rate is on average close to $5-10 \mathrm{~cm} / \mathrm{k} . \mathrm{y}$. (see site chapters in Cochran, Stow, et al., 1988). However, there were fluctuations in sediment accumulation between nondeposition and erosion, especially during the Pleistocene. Intermediate sedimentation rates of 5-10 $\mathrm{cm} / \mathrm{k}$.y. for mud turbidites and rapid deposition $>15-20$ $\mathrm{cm} / \mathrm{k}$.y. were determined for late Pleistocene sediments.

At Site 717 the following lithologic Units were defined:

I. 0.0-5.5 mbsf: muds, mud turbidites and pelagites (Holocene to latest Pleistocene).

II. 5.5-152.0 mbsf: micaceous silty turbidites with thin intervening muds and calcareous clays (late Pleistocene).

III. 152.0-302.0 mbsf: biogenic mud turbidites and mud turbidites with thin interbedded pelagic clays (Pleistocene and late Pliocene).

IVA. 302.0-335.0 mbsf: silt turbidites with thin muds and mud turbidites (early Pliocene).

\footnotetext{
${ }^{1}$ Cochran, J. R., Stow, D.A.V., et al., 1990. Proc. ODP, Sci. Results, 116: College Station, TX (Ocean Drilling Program).

2 Geologisch-Paläontologisches Institut der Universităt, Sigwartstra $\beta$ e 10 , D 7400 Tübingen, Federal Republic of Germany.

${ }^{3}$ Present address: Geologisch-Paläontologisches Institut der Universität, Bernouillstraße 32, CH 4056 Basel, Switzerland.
}

IVB. 335.0-456.0 mbsf: mud turbidites with interbedded pelagic clays (early Pliocene to late Miocene).

IVC. 456.0-465.2 mbsf: silt and silt to mud turbidites with minor amounts of mud (late Miocene).

IVD. 465.2-533.2 mbsf: mud turbidites with interbedded pelagic clays (late Miocene).

V. $533.2-828.2$ mbsf: silt and silt to mud turbidites with rare intervals of pelagic clay and organic-rich mud turbidites (late Miocene).

At Site 718 the following lithologic Units were defined:

I. 0.0-2.0 mbsf: clay and calcareous clay (latest Pleistocene).

II. 2.0-100.0 mbsf: micaceous silt and silty mud turbidites (late Pleistocene).

III, IV. 100.0-185.0 mbsf: mud turbidites with thin interbedded pelagic clays and scattered silty mud turbidites (Pleistocene to late Miocene).

VA. 185.0-605.0 mbsf: silt and silty mud turbidites with thin, sporadic interbeds of pelagic clays (late to middle Miocene).

VB. 605.0-961.0 mbsf: silt and silty mud turbidites with up to 20 -m-thick intervals of interbedded mud turbidites, biogenic mud turbidites and pelagic clays (middle to early Miocene).

The section drilled at Site 719 was divided into the following lithologic Units:

I. 0.0-4.0 mbsf: clay and calcareous clay and mud (Holocene to latest Pleistocene).

II. 4.0-135.0 mbsf: micaceous silt and silty turbidites with thin intervening muds (late Pleistocene).

III. 135.0-207.0 mbsf: mud turbidites and biogenic mud turbidites with thin interbedded pelagic clays (Pleistocene to early Pliocene).

IVA. 207.0-240.0 mbsf: silt turbidites with thin muds and mud turbidites (early Pliocene).

IVB. $240.0-357.0$ mbsf: mud turbidites with thin interbedded pelagic clays (early Pliocene to late Miocene). 


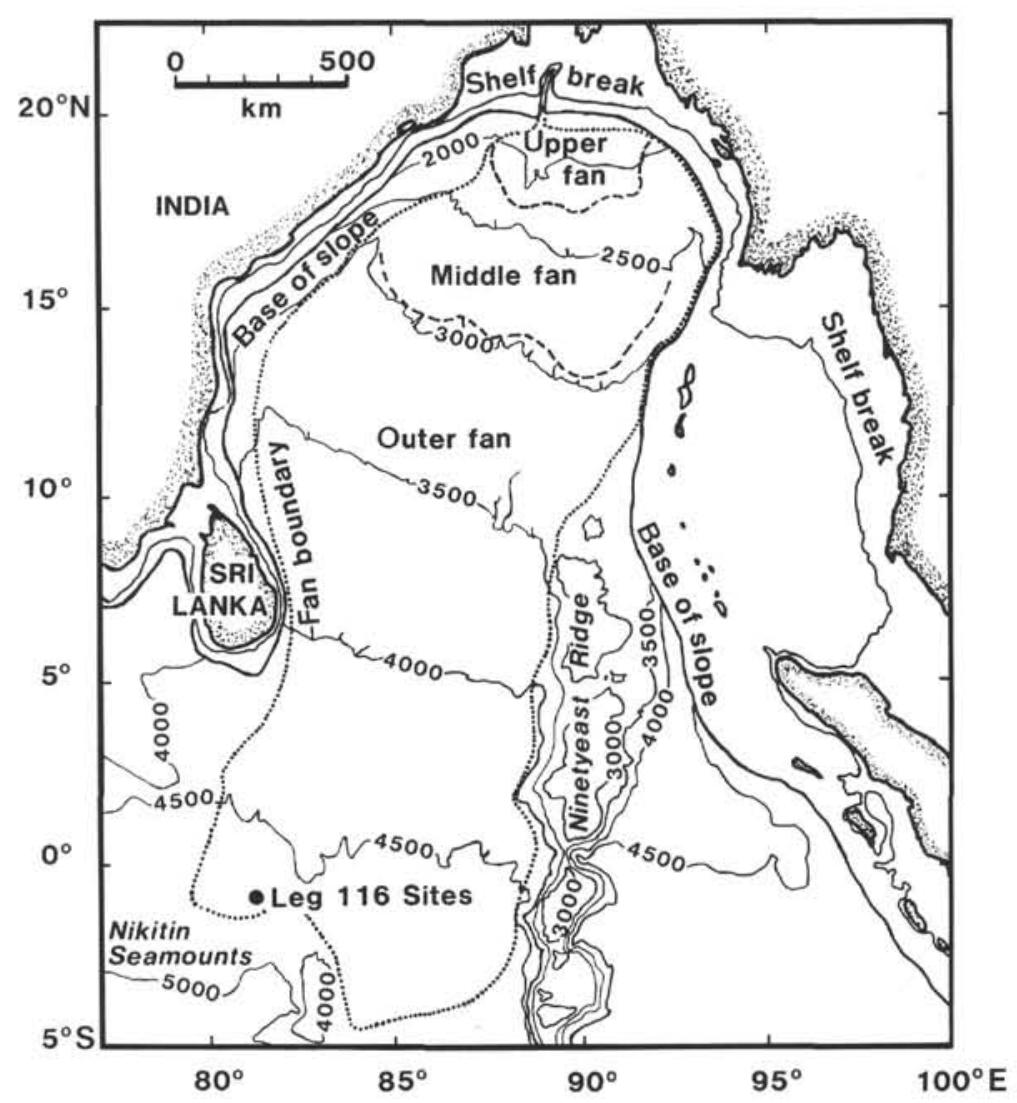

Figure 1. Location of sites drilled during Leg 116. Depth contours are in meters.

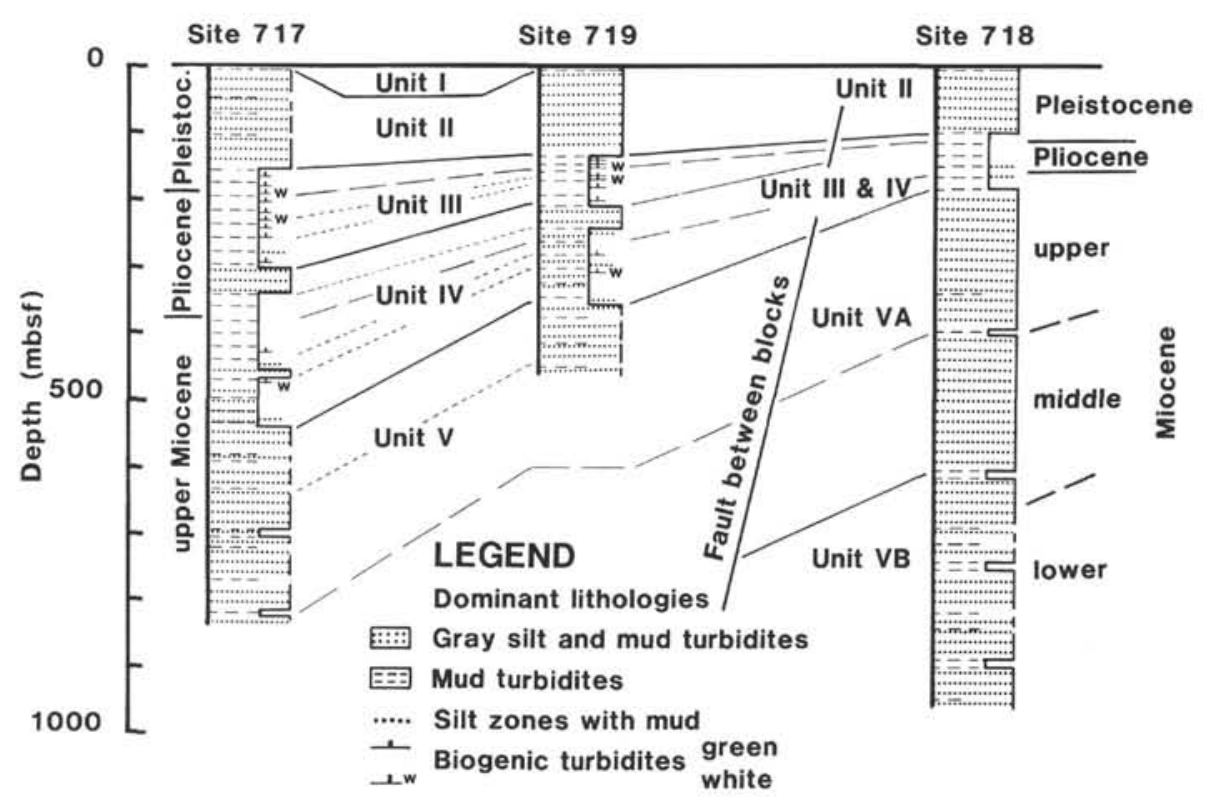

Figure 2. Dominant lithologic units as defined at the drilled sites for outer Bengal Fan deposits.

V. 357.0-460.2 mbsf: silt and silty mud turbidites with rare intervals of pelagic clay and organic-rich mud turbidites.

The outer Bengal Fan sediments preserve a record of the compressional deformation experienced by the oceanic lithosphere of the central Indian Ocean Basin south of India. The increased resistance to subduction and shortening across the
Himalaya, combined with continued seafloor spreading of the Southeast Indian Ridge, implies that the central Indian Ocean is under a strong north-south compressive stress regime. Within the investigation area both the oceanic crust and the overlying sediments are deformed by intraplate stresses resulting in faulting and long-wave folding (Fig. 3). Within the investigation area uplift as much as $350 \mathrm{~m}$ across a fault was 


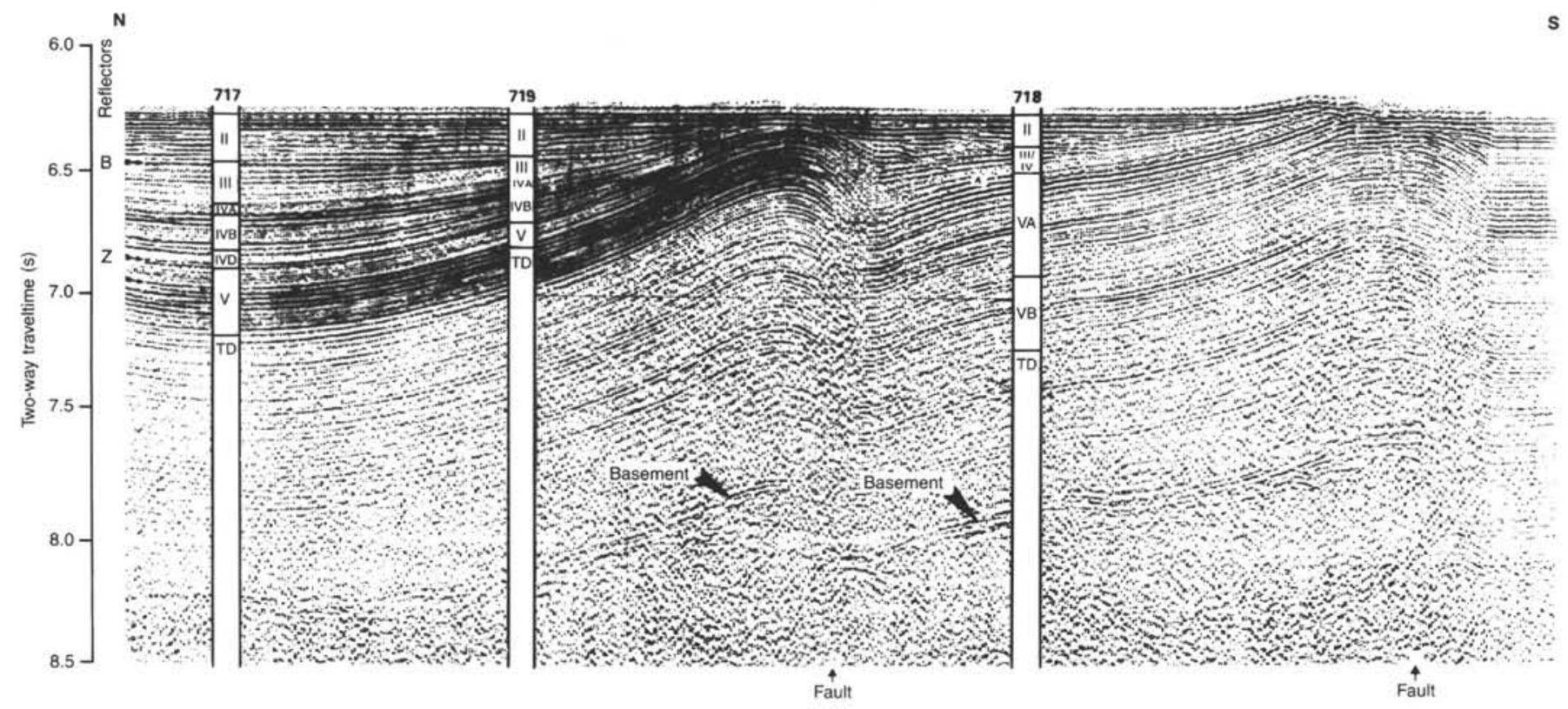

Figure 3. Single-channel seismic line (CONRAD 2706) running north-south through Leg 116 sites. Roman numerals at each site denote the lithologic units drilled. Note unconformity between lithologic Units II and III, especially at Sites 719 and 718 . For details see text.

determined. Further hints on tectonic activity came from heat flow measurements showing anomalously high heat flows in areas where faults cut to the seafloor (Weissel et al., 1980).

The specific situation in the investigation area, therefore, makes it desirable to have further information on (1) the permeability of the deposits, which is of interest for estimating hydrothermal circulation, and (2) the state of consolidation that allows estimation of fabric strength in relation to overburden, and hence, loss of overburden by erosion, diagenetic cementation, or the influence of pore-water overpressure. These parameters can be obtained by consolidation tests. It is the purpose of this paper to provide such data and relate them to the history of the deposits.

\section{MATERIAL}

Only fine-grained, cohesive material was tested since silty and sandy deposits were too disturbed by drilling to obtain reasonable results. Whole-round samples $7 \mathrm{~cm}$ in diameter were available for consolidation tests.

\section{METHODS}

The methods applied in this study to determine the compressibility, the state of consolidation, and the permeability of the deposits were (1) compression tests, and (2) calculation of the overburden stress.

Standardized consolidation tests were carried out to evaluate the sediment response to an applied load (e.g., Schultze and Muhs, 1967; Terzaghi and Peck, 1967; Attewell and Farmer, 1976). In the test a sediment volume is compressed by applying known different stresses under confined conditions in an oedometer (Fig. 4). For initial loading conditions Terzaghi (1925) gave the following equation

$$
\mathrm{e}_{\mathrm{x}}=\mathrm{e}_{\mathrm{x}+1}+\mathrm{C}_{\mathrm{c}} \lg \left(\sigma_{\mathrm{x}+1} / \sigma_{\mathrm{x}}\right)
$$

where $\mathrm{e}_{\mathrm{x}}$ is the void ratio at stress $\sigma_{\mathrm{x}}$, and $\mathrm{e}_{\mathrm{x}+1}$ is the void ratio at a higher stress level $\sigma_{\mathrm{x}+1}, \mathrm{C}_{\mathrm{c}}$ is the compression index.

Furthermore, compression tests allow determination of the relative degree of consolidation (expressed as a stress value,

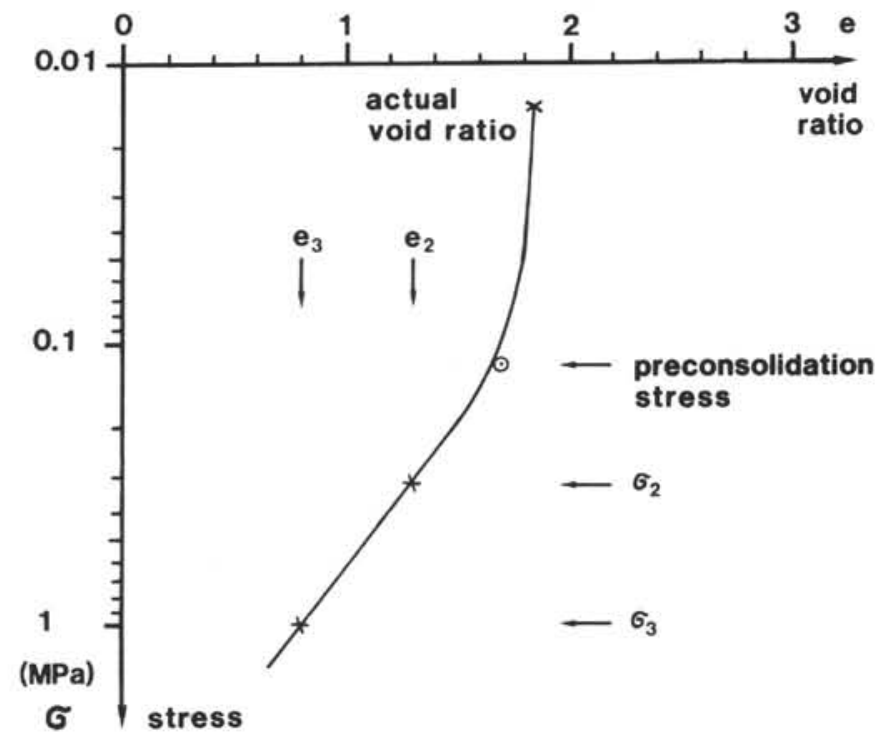

Figure 4. Hypothetical curve of void ratio (e) vs. log effective stress showing typical compression behavior of a preconsolidated sediment. After the preconsolidation stress $\left(\sigma_{\mathcal{c}}\right)$ is reached a linear relationship between void ratio and log stress is found; the slope of the graph is defined as compression index $\left(C_{c}\right)$ by the equation $e_{3}=e_{2}-C_{c}$ $\lg \left(\sigma_{2} / \sigma_{3}\right)$.

the so-called "preconsolidation stress") that the sediment has experienced in situ under the sedimentary overburden or by diagenetic cementation (or alteration) of the components. Preconsolidation stress $\left(\sigma_{\mathrm{c}}\right)$ is usually calculated by using the graphical reconstruction technique of Casagrande (1936). However, recent investigations show that the values determined by this method are often too low (Marine Geotechnical Consortium, 1985). Therefore, in this paper a modified method is applied which is described in detail by the Marine Geotechnical Consortium (1985) and Bryant et al. (1986). 
The overburden stress $\left(\sigma_{z}\right)$ was calculated using the onboard results of wet bulk density $\left(\rho_{\uparrow}\right)$. The following equation was applied

$$
\left.\sigma_{\mathrm{z}}(\mathrm{MPa})=\rho_{\mathrm{f}}-\rho_{\mathrm{w}}\right)\left(\mathrm{g} / \mathrm{cm}^{3}\right) \mathrm{z}(100 \mathrm{~m})
$$

where $\rho_{\mathrm{f}}$ is the average value of the wet-bulk density for the depth interval from seafloor to depth $\mathrm{z}$, and $\rho_{\mathrm{w}}$ is the density of the pore water that is assumed to be close to that of seawater $\left(1.025 \mathrm{~g} / \mathrm{cm}^{3}\right)$.

The preconsolidation stress $\left(\sigma_{c}\right)$ was related to the overburden stress $\left(\sigma_{\mathrm{w}}\right)$ defining the overconsolidation ratio (OCR)

$$
\mathrm{OCR}=\sigma_{\mathrm{c}} / \sigma_{\mathrm{z}}
$$

Long-term compression tests (lasting up to 10 weeks) were carried out to allow determination of primary as well as secondary compression parameters. The permeability of the sample then can be calculated using the formula

$$
\mathrm{k}=\mathrm{c}_{\mathrm{v}}(1+\mathrm{e}) / \rho_{\mathrm{w}} \mathrm{m}_{\mathrm{v}}=\mathrm{c}_{\mathrm{v}} / \rho_{\mathrm{w}} \mathrm{m}_{\mathrm{v}}
$$

with $\mathrm{k}$ coefficient of permeability $(\mathrm{cm} / \mathrm{s}), \mathrm{c}_{\mathrm{v}}$ coefficient of consolidation $\left(=0.848 \mathrm{H}^{2} / \mathrm{t}_{90}\right.$ with $\mathrm{H}$ average drainage height of the sample and $t_{90}$ time required for $90 \%$ completion of primary consolidation), e void ratio, $\rho_{\mathrm{w}}$ density of pore water (assumed to equal $1.025 \mathrm{~g} / \mathrm{cm}^{3}$ ), and $\mathrm{m}_{\mathrm{v}}$ coefficient of volume change $(=(\mathrm{de} / \mathrm{d} \sigma) /(1+\mathrm{e}))$.
It is interesting to note that the results of calculated permeabilities from consolidation tests are usually half to one order of magnitude less than from direct measurements using the free-falling head technique (Marine Geotechnical Consortium, 1985).

\section{RESULTS}

The results of the compression test are listed in Table 1 and are shown graphically in Figures 5 and 6.

The compressibility of the outer Bengal Fan deposits expressed as compression index $\left(C_{c}\right)$ varies between 0.04 and 1.1 , but most sediments show a value of $0.3-0.5$, which is typical for marine silts and clays (e.g., Bryant et al., 1981). The variation of the compression index corresponds to the lithologic composition of the samples (Fig. 5).

Permeability varies between $2.1 \times 10^{-4} \mathrm{~cm} / \mathrm{s}$ and $8.9 \times 10^{-9}$ $\mathrm{cm} / \mathrm{s}$ which is also typical for fine-grained marine deposits (e.g., Schultheiss and Gunn, 1985).

The state of consolidation varies between underconsolidation $(\mathrm{OCR} \approx 0.7)$ and overconsolidation $(\mathrm{OCR} \approx 1.6)$, but most sediments are classified to be normally consolidated. The value of the OCR for a sample depends on the applied method to evaluate it. Generally, the graphical reconstruction method by Casagrande (1936) provides lower values than that of the Marine Geotechnical Consortium

\begin{tabular}{|c|c|c|c|c|c|c|c|c|}
\hline $\begin{array}{l}\text { Core, } \\
\text { section }\end{array}$ & $\begin{array}{l}\text { Depth } \\
\text { (mbsf) }\end{array}$ & $\begin{array}{c}\sigma_{\mathrm{z}} \\
(\mathrm{kPa})\end{array}$ & $e_{z}$ & $\sigma_{\mathrm{c}}^{\mathrm{a}}(\mathrm{kPa})$ & $\mathrm{OCR}^{\mathrm{a}}$ & $\mathrm{C}_{\mathrm{c}}$ & $\mathrm{k}_{\mathrm{f}}(\mathrm{cm} / \mathrm{s})$ & $e_{c}^{a}$ \\
\hline \multicolumn{9}{|l|}{$116-717 \mathrm{C}$ - } \\
\hline 3-1 & 17.35 & 128 & 0.60 & $141-178$ & $1.09-1.38$ & 0.11 & $3.8 \times 10^{-5}$ & $0.59-0.58$ \\
\hline $10-1$ & 75.55 & 577 & 0.98 & $524-600$ & $0.91-1.04$ & 0.55 & $2.1 \times 10^{-4}$ & $1.00-0.95$ \\
\hline $10-1$ & 75.95 & 580 & 0.39 & $550-586$ & $0.95-1.01$ & 0.08 & $7.6 \times 10^{-8}$ & $0.39-0.38$ \\
\hline $15-1$ & 113.95 & 899 & 0.67 & $731-944$ & $0.82-1.05$ & 0.14 & $5.0 \times 10^{-8}$ & $0.69-0.65$ \\
\hline $21-3$ & 164.45 & 1359 & 1.02 & $1266-1584$ & $0.93-1.16$ & 0.43 & $1.7 \times 10^{-7}$ & $1.05-1.00$ \\
\hline $25-3$ & 202.45 & 1724 & 0.78 & $1995-2042$ & $1.16-1.18$ & 0.65 & $5.7 \times 10^{-7}$ & $0.75-0.74$ \\
\hline $29-3$ & 240.45 & 2088 & 0.68 & $2188-2630$ & $1.05-1.26$ & 0.66 & $5.7 \times 10^{-7}$ & $0.66-0.57$ \\
\hline $33-4$ & 279.95 & 2467 & 0.66 & $2344-2570$ & $0.95-1.04$ & 0.36 & $4.0 \times 10^{-7}$ & $0.67-0.65$ \\
\hline $37-1$ & 313.45 & 2796 & 0.47 & $2630-2951$ & $0.94-1.06$ & 0.30 & $8.4 \times 10^{-7}$ & $0.58-0.55$ \\
\hline $42-3$ & 363.95 & 3306 & 0.73 & $3236-3548$ & $0.98-1.07$ & 0.35 & $8.6 \times 10^{-7}$ & $0.40-0.36$ \\
\hline $46-2$ & 400.45 & 3675 & 0.68 & $3467-3802$ & $0.99-1.04$ & 0.51 & $7.8 \times 10^{-8}$ & $0.70-0.66$ \\
\hline $50-4$ & 441.45 & 4089 & 0.78 & $3802-5012$ & $0.93-1.23$ & 0.44 & $8.3 \times 10^{-7}$ & $0.80-0.73$ \\
\hline $54-3$ & 477.95 & 4457 & 0.30 & $3981-5011$ & $0.89-1.12$ & 0.28 & $2.2 \times 10^{-8}$ & $0.32-0.28$ \\
\hline $58-4$ & 517.45 & 4870 & 0.31 & $4786-5248$ & $0.98-1.08$ & 0.30 & $8.6 \times 10^{-7}$ & $0.32-0.30$ \\
\hline $65-3$ & 582.45 & 5539 & 0.34 & $4898-5888$ & $0.88-1.06$ & 0.32 & $8.9 \times 10^{-9}$ & $0.37-0.33$ \\
\hline $69-2$ & 618.95 & 5917 & 0.33 & $5623-6607$ & $0.95-1.12$ & 0.37 & $8.9 \times 10^{-8}$ & $0.32-0.29$ \\
\hline $76-3$ & 686.95 & 6624 & 0.12 & $6606-7586$ & $0.99-1.15$ & 0.29 & $1.1 \times 10^{-8}$ & $0.12-0.11$ \\
\hline $80-3$ & 724.95 & 7020 & 0.23 & $7100-8710$ & $1.01-1.25$ & 0.26 & $1.1 \times 10^{-8}$ & $0.23-0.20$ \\
\hline $90-1$ & 810.65 & 7927 & 0.29 & $7762-8913$ & $0.98-1.13$ & 0.45 & $1.1 \times 10^{-8}$ & $0.30-0.26$ \\
\hline \multicolumn{9}{|l|}{ 116-718B- } \\
\hline $3-1$ & 29.72 & 208 & 0.87 & $251-501$ & $1.21-2.41$ & 0.22 & $1.4 \times 10^{-5}$ & $0.86-0.82$ \\
\hline $11-1$ & 105.73 & 743 & 1.40 & $575-626$ & $0.77-0.84$ & 0.48 & $3.3 \times 10^{-6}$ & $1.55-1.49$ \\
\hline $19-2$ & 183.23 & 1328 & 0.65 & $2138-2291$ & $1.61-1.73$ & 0.40 & $2.2 \times 10^{-7}$ & $0.54-0.52$ \\
\hline $29-1$ & 276.68 & 2206 & 0.48 & $2511-2818$ & $1.14-1.28$ & 0.16 & $8.5 \times 10^{-7}$ & $0.47-0.46$ \\
\hline $37-1$ & 352.73 & 2970 & 0.48 & $3388-3630$ & $1.14-1.22$ & 0.43 & $5.6 \times 10^{-6}$ & $0.46-0.44$ \\
\hline $47-1$ & 447.73 & 3861 & 0.29 & $3467-4074$ & $0.90-1.06$ & 0.22 & $5.3 \times 10^{-8}$ & $0.31-0.28$ \\
\hline $61-1$ & 580.73 & 5195 & 0.34 & $4786-5623$ & $0.92-1.08$ & 0.24 & $3.3 \times 10^{-7}$ & $0.37-0.34$ \\
\hline $71-2$ & 677.23 & 6149 & 0.23 & $6607-6921$ & $1.07-1.13$ & 0.16 & $5.8 \times 10^{-7}$ & $0.22-0.21$ \\
\hline \multicolumn{9}{|l|}{ 116-719A- } \\
\hline $1-1$ & 0.78 & 2 & 3.51 & 2-2 & 1 & 1.10 & $1.1 \times 10^{-5}$ & $3.40-3.35$ \\
\hline $11-1$ & 90.73 & 715 & 0.64 & $479-650$ & $0.67-0.91$ & 0.24 & $1.4 \times 10^{-5}$ & $0.70-0.65$ \\
\hline $28-4$ & 257.13 & 2138 & 0.68 & $2344-2630$ & $1.10-1.23$ & 0.84 & $6.8 \times 10^{-6}$ & $0.65-0.60$ \\
\hline $39-1$ & 356.98 & 2969 & 0.49 & $3311-3715$ & $1.12-1.23$ & 0.48 & $1.3 \times 10^{-7}$ & $0.48-0.45$ \\
\hline $48-3$ & 445.63 & 3825 & 0.76 & $3350-4521$ & $0.88-1.18$ & 0.40 & $1.3 \times 10^{-7}$ & $1.10-0.73$ \\
\hline
\end{tabular}
(1985).

Table 1. Consolidation characteristics of outer Bengal Fan deposits.

a Minimum values were obtained by the method of Casagrande (1936) and maximum values by the method suggested by the Marine Geotechnical Consortium (1985). 


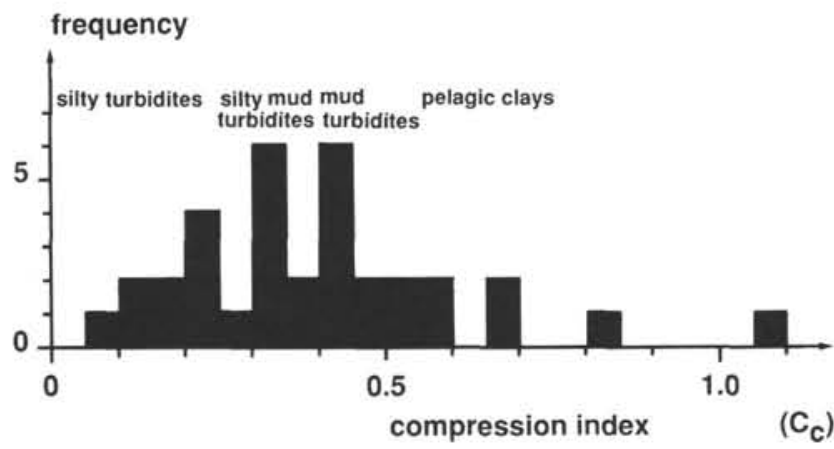

Figure 5. Frequency distribution of compression index determined for outer Bengal Fan deposits. The compression index varies in correspondence to lithology. The occurrence of distinct maxima reflects the predominance of certain sediment types in the investigation area.

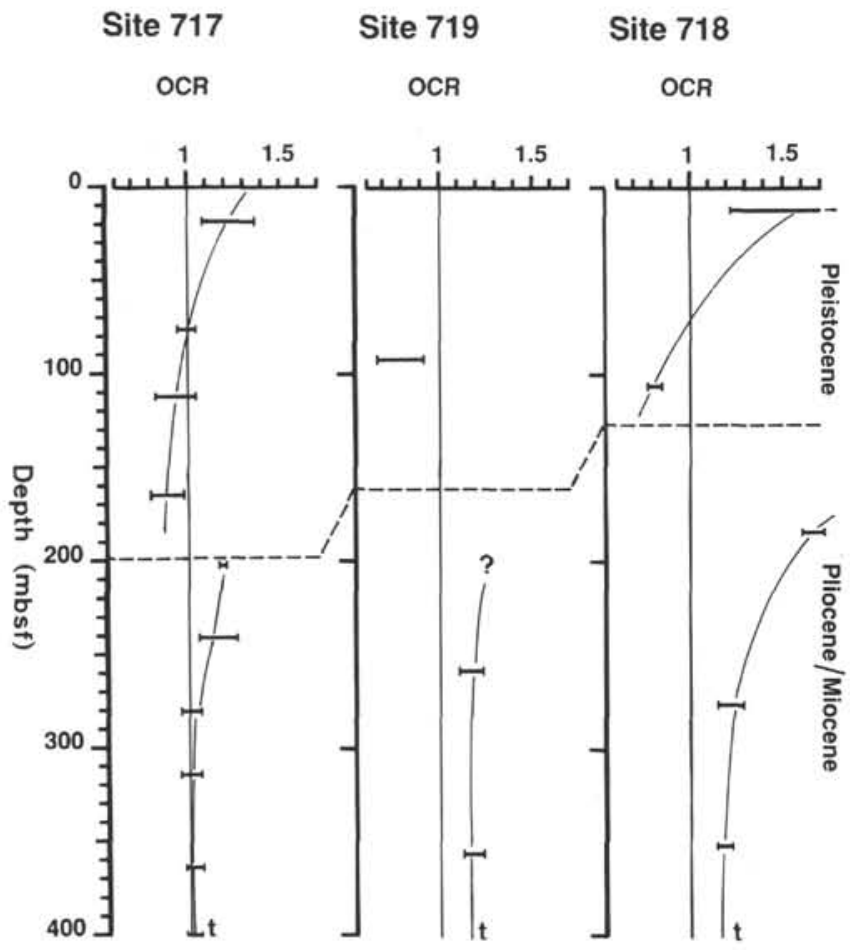

Figure 6. State of consolidation of outer Bengal Fan deposits vs. depth. OCR represents overconsolidation ratio, $\mathrm{OCR}=1$ is normally consolidated, OCR $>1$ is overconsolidated, and OCR $<1$ is underconsolidated. Bars refer to different OCR values obtained by the method of Casagrande (1936) representing the lower value, whereas the higher values were obtained by the method suggested by the Marine Geotechnical Consortium (1985), t reflects the general trend. The variations in state of consolidation observed at all three sites at the Pleistocene/Pliocene boundary probably indicate erosion during early Pleistocene times. The early Pleistocene section is underconsolidated supposedly due to rapid sedimentation.

\section{DISCUSSION}

The determined consolidation characteristics and their variation with depth need to be discussed in more detail.

At all three sites similar variations in the state of consolidation (expressed as OCR values) were observed, but they are most clearly developed within Site 718 sediments. Two sections can be distinguished each showing decreasing overconsolidation ratio $(\mathrm{OCR})$ values downward; (1) Present to early
Pleistocene deposits, and (2) late Pliocene to Miocene sediments. A sharp boundary occurs between overconsolidated late Pliocene and underconsolidated Pleistocene deposits. This boundary coincides with that between the lithologic Units II and III. At each Site, below $300-400$ mbsf the OCR reaches values typical for normally consolidated deposits.

The overconsolidation of the late Pliocene sediments is of interest because the early Pleistocene (older than 500 k.y.) was not recovered at all three sites (see site chapters in Cochran, Stow, et al., 1988). From the results of the compression tests the amount of erosion can be estimated using the overburden stress-depth relationship established for the drilled sites (see site chapters in Cochran, Stow, et al., 1988). The preconsolidation stress at the $190 \mathrm{mbsf}$ level at Site 718 (about $70 \mathrm{~m}$ below the Pliocene/Pleistocene boundary) corresponds to an overburden stress found today at about 200-220 mbsf. Reconstructing the depth level of the seafloor and the overburden vs. depth path at about 500 k.y.B.P. (just before erosion occurred), the amount of erosion that must have been occurred thereafter can be estimated by $130-150 \mathrm{~m}$. At Sites 717 and 719 the amount of erosion is in the range of $10-40 \mathrm{~m}$. The differing amount of erosion might be caused by the unequal uplift of the underlying blocks during intraplate deformation. Thereby, first erosion occurred at highest elevations followed by nondeposition. This interpretation is supported by the seismic record (Fig. 3). The relative uplift of the block on which Site 718 is located is in the range of the estimated amount of erosion (see site chapters in Cochran, Stow, et al., 1988).

The lower part of the recovered Pleistocene sediments are slightly underconsolidated at deeper levels $(\mathrm{OCR}=0.7-0.9)$, whereas the deposits of the upper part are overconsolidated. The underconsolidation in the lower part may result from more rapid accumulation; the minimum degree of underconsolidation is in the possible range given by Morgenstern (1967) for sediments deposited at rates of $20-50 \mathrm{~cm} / \mathrm{k}$.y. In contrast, the sediments situated closer to the surface may be more slowly deposited and, hence, they can sufficiently dewater even through low-permeable deposits. However, because of poor time control within the sediments, the deduction of a decreasing sedimentation rate within lithologic Unit II must be tentative.

\section{CONCLUSIONS}

1. The consolidation parameters compression index and permeability for the outer Bengal Fan sediments drilled during Leg 116 are in the range typical for fine-grained marine sediments. The compression index varies according to lithology between about 0.1 for silts and 1.1 for organic rich clays. The permeability decreases downward from $10^{-4} \mathrm{~cm} / \mathrm{s}$ at the seafloor to about $10^{-9} \mathrm{~cm} / \mathrm{s}$ in some hundreds of meters depth.

2. Most of the outer Bengal Fan deposits are normally consolidated. Deviations from normal consolidation are related to the depositional history of the sediments.

(a) At all sites the sediments within lithologic Unit IIcomprising sandy/silty turbidites-are underconsolidated below the $60-80$ mbsf depth level. The underconsolidation is very probably caused by rapid sedimentation $(>15-20 \mathrm{~cm} /$ k.y.) and low permeability $\left(<10^{-7} \mathrm{~cm} / \mathrm{s}\right)$. Sedimentation of this unit is about four times faster than of the underlying one.

(b) Overconsolidation occurs at the top of lithologic Unit III which mainly consists of mud turbidites. Overconsolidation is believed to result from erosion of a $10-40 \mathrm{~m}$ thick sediment layer at Sites 717 and 719 and $130-150 \mathrm{~m}$ or more at Site 718. This interpretation is supported by a gap within the stratigraphic record; lower Pleistocene sediments-corresponding to a time interval of more than 500 k.y.-were not 
encountered at all three sites. The estimated amount of erosion seems to reflect the amount of block movement during intraplate deformation.

\section{ACKNOWLEDGMENTS}

Financial support by the Deutsche Forschungsgemeinschaft is gratefully acknowledged.

\section{REFERENCES}

Attewell, P. B., and Farmer, I. W., 1976. Principles of Engineering Geology: London (Chapman \& Hall).

Bryant, W. R., Bennett, R., and Katherman, C., 1981. Shear strength, consolidation, porosity, and permeability of oceanic sediments. In Emiliani, C. (Ed.), The Sea (Vol. 7): New York (Wiley), 1555-1616.

Bryant, W. R., Wetzel, A., Taylor, E., and Sweet, W. E., 1986. Consolidation characteristics and permeability of Mississippi Fan sediments. In Bouma, A. H., Coleman, J. M., Meyer, A. W., et al., Init. Repts. DSDP, 96: Washington (U.S. Govt. Printing Office), 797-809.

Casagrande, A., 1936. The determination of the preconsolidation load and its practical significance. Proc. First Inter. Conf. Soil Mech. and Found. Eng., 3:60-64.
Marine Geotechnical Consortium, 1985. Geotechnical properties of northwest Pacific pelagic clays: Deep Sea Drilling Project Leg 86, Site 576 A. In Heath, R. C., Burckle, L. H., et al., Init. Repts. DSDP, 86: Washington (U.S. Govt. Printing Office), 723-758.

Morgenstern, N. R., 1967. Submarine slumping and the initiation of turbidity currents. In Richards, A. F. (Ed.), Marine Geotechnology: Urbana (Univ. Illinois Press), 189-220.

Schultheiss, P. J., and Gunn, D. E., 1985. The permeability and consolidation of deep-sea sediments. Inst. Oceanogr. Sci. Rep., 201.

Schultze, E., and Muhs, H., 1967. Bodenuntersuchungen für Ingenieurbauten (2nd ed.): Berlin (Springer).

Terzaghi, K., 1925. Erdbaumechanik auf bodenphysikalischer Grundlage: Leipzig (Deuticke).

Terzaghi, K., and Peck, R. B., 1967. Soil Mechanics in Engineering Practice (2nd ed.): New York (Wiley).

Weissel, J. K., Anderson, R. N., and Geller, C. A., 1980. Deformation of the Indo-Australian plate. Nature, 287:284-291.

Date of initial receipt: 19 December 1988

Date of acceptance: 3 January 1990

Ms 116B-145 